\title{
Urgences
}

\section{Ainsi, dites-vous...}

\section{Marcel Labine}

Numéro 15, octobre 1986

Épigraphiques

URI : https://id.erudit.org/iderudit/025315ar

DOI : https://doi.org/10.7202/025315ar

Aller au sommaire du numéro

Éditeur(s)

Urgences

ISSN

0226-9554 (imprimé)

1927-3924 (numérique)

Découvrir la revue

Citer ce document

Labine, M. (1986). Ainsi, dites-vous... Urgences, (15), 50-50.

https://doi.org/10.7202/025315ar

Ce document est protégé par la loi sur le droit d'auteur. L'utilisation des services d'Érudit (y compris la reproduction) est assujettie à sa politique d'utilisation que vous pouvez consulter en ligne.

https://apropos.erudit.org/fr/usagers/politique-dutilisation/
Cet article est diffusé et préservé par Érudit.

Érudit est un consortium interuniversitaire sans but lucratif composé de l’Université de Montréal, l'Université Laval et l'Université du Québec à Montréal. Il a pour mission la promotion et la valorisation de la recherche. https://www.erudit.org/fr/ 


\section{Marcel Labine}

Chaque membre fatigué comme un homme.

Franz Kafka: Feuillets de conversation

Ainsi, dites-vous, nous en serions à la dernière extrémité! Nous ne pèserions pas lourd entre les draps et les feuilles! Mais nous pesons encore un peu non pas tant par la force qu'il nous reste que par l'habitude que nous avons prise de cette posture - horizontale, évidemment, toujours, depuis le début donc. Alors, conséquemment, vous vous demandez bien ce qu'il nous reste à faire, là, sans force, nu et maigre. Vous vous le demandez avec d'autant plus d'impatience presque avec fébrilité, mais là c'est un leurre, vous le savez bien qu'il ne peut être question de se redresser et de s'asseoir, boire ou lire.

\section{Alors?}

Alors ceci. Avec ce qu'il nous reste d'ingéniosité et de perversité mais est-ce bien là les mots qu'il faut? - donc ainsi, avec disons, l'énergie et la patience présentes ici demeure une exécution qui à première vue peut sembler définitive. Mais prenez garde, ce n'est qu'une amorce. Alors ceci: balancez-vous, balançons-nous sur notre dos jusqu'à ce que vienne, de la gauche ou de la droite, peu importe la première fois, malgré la fatigue, malgré les membres, malgré en définitive l'ensemble de notre condition, une force suffisante pour imprimer entre les feuilles, entre les draps, un mouvement cohérent à la totalité de notre corps ou du vôtre qui, le temps aidant, ressemblera à s'y méprendre aux torsions d'une vrille et où il sera possible pour tous les gens qui regarderont de près, les premiers temps, d'observer dans votre image chaque homme fatigué comme un membre.

p.s.: répéter six fois par jour, ou au besoin. 